\title{
An Open-Label Prospective Pilot Trial of Nucleus Accumbens Deep Brain Stimulation for Children with Autism Spectrum Disorder and Severe, Refractory Self- Injurious Behaviour: Study Protocol
}

Han Yan

SickKids: The Hospital for Sick Children https://orcid.org/0000-0002-0494-0214

\section{Lauren Siegel}

SickKids: The Hospital for Sick Children

\section{Sara Breitbart}

SickKids: The Hospital for Sick Children

\section{Carolina Gorodetsky}

SickKids: The Hospital for Sick Children

\section{Alfonso Fasano}

University Health Network

\section{Aliya Rahim}

SickKids: The Hospital for Sick Children

\section{Alvin Loh}

Surrey Place Centre

\section{Abhaya V. Kulkarni}

SickKids: The Hospital for Sick Children

George M. Ibrahim ( $\sim$ george.ibrahim@sickkids.ca )

The Hospital for Sick Children https://orcid.org/0000-0001-9068-8184

\section{Study Protocol}

Keywords: Autism spectrum disorder, Deep brain stimulation, Children, Self-injurious behaviour, Nucleus accumbens

Posted Date: April 27th, 2021

DOl: https://doi.org/10.21203/rs.3.rs-440618/v1

License: (c) (i) This work is licensed under a Creative Commons Attribution 4.0 International License. Read Full License

Version of Record: A version of this preprint was published at Pilot and Feasibility Studies on February 2nd, 2022. See the published version at https://doi.org/10.1186/s40814-022-00988-3. 


\section{Abstract \\ Background}

Children and youth with Autism Spectrum Disorder (ASD) may manifest self-injurious behaviours (SIB) that may become severe and refractory with limited pharmacologic or behavioural treatment options. Here, we present the protocol of a prospective, mixed-methods study to assess the safety and efficacy of deep brain stimulation (DBS) of the nucleus accumbens (NAcc) for children and youth with ASD and severe, refractory SIB.

\section{Methods}

This is a prospective, single-center, single-cohort, open-label, non-randomized pilot trial of 6 patients. Participants will be recruited through specialized behavioural clinics with persistent severe and refractory SIB following standard and intensive interventions. Following NAcc-DBS, participants will be enrolled in the study for 12 months. The primary objectives of the study are safety and feasibility, assessed by rate of recruitment and identification of factors impacting adherence to follow-up and study protocol. Treatment efficacy will be assessed by changes in the Children's Yale-Brown Obsessive-Compulsive Scale (CY-BOCS), the Behaviour Problems Index (BPI), the Inventory of Statements about Self-Injury (ISAS) and the Repetitive Behaviour ScaleRevised (RBS-R) questionnaires. Additional clinical outcomes will be assessed, including measures of participant and caregiver quality of life, actigraph measurements, and positron emission tomography (PET) changes following DBS.

\section{Discussion}

This study will be the first to evaluate the effect of DBS of the NAcc on a pediatric population in a controlled, prospective trial. Secondary outcomes will improve the understanding of behavioural, neuro-imaging and electrophysiologic changes in children with ASD and SIB treated with DBS. This trial will provide an estimated effect size of NAcc-DBS for severe refractory SIB in children with ASD in preparation for future comparative trials.

\section{Trial Registration}

Registration on ClinicalTrials.gov was completed on June 12 of 2019 with the Identifier: NCT03982888. https://clinicaltrials.gov/ct2/show/NCT03982888

\section{Background}

Autism spectrum disorder (ASD) is a clinical diagnosis based on a set of heterogeneous neurodevelopmental conditions. ASD is characterized by difficulties in social interaction and communication, and repetitive restricted behaviours and interests according to the Diagnostic and Statistical Manual of Mental Disorders, 5th edition (DSM-V).(1) ASD has a worldwide prevalence of 1\%, an estimated 1 in 68 births in the United States in 2014 by the Centre for Disease Control and Prevention, and a greater prevalence in males than females.(2-4) 
The behavioural comorbidities of ASD include aggressive behaviour (up to 68\%) $(5,6)$ and repetitive self-injurious behaviour (up to $50 \%) .(7,8)$ In children with ASD and self-injurious behaviours (SIB), over $75 \%$ of children will have persistence of these behaviours into adulthood, sometimes resulting in severe harm and even death. $(5,9-$ 11) SIB can be defined as repetitive "behaviour which produces physical injury to the individual's own body" with several different subclassifications.(12) Pharmacologic agents, such as antipsychotics (e.g. risperidone, aripiprazole), and selective serotonin reuptake inhibitors (e.g. fluoxetine) show evidence for treating irritability but not specifically reducing self-injury.(13-17)

Applied behaviour analysis, based on operant methodology, offers an evidence-based method to assess and treat SIB. Functional analysis identifies the function of the behaviour and shows what conditions self-injury are associated with and what stimulus conditions maintain it.(18) It is hypothesized that social consequences, such as escape from demands or selective attention, mediate $20-25 \%$ of SIB through automatic reinforcement.(12, 19) Subtypes of automatic reinforcement show differential responses to reinforcement-based interventions and may have implications on the biological bases of SIB and biobehavioural research. This may also give us insight into the role of neuromodulation as a feasible intervention for SIB.

Neuromodulation, through deep brain stimulation (DBS), may present novel treatment options for this population when other treatments are not effective or tolerated. DBS is a precise neuromodulation strategy for targeting pathological brain circuity,(20) albeit with incompletely understood mechanisms of action. DBS involves implantation of electrodes (often two with one on each side of the brain) into deep brain targets and delivery of an electrical current through these electrodes via an impulse generator implanted in the chest. The indication for DBS in pediatric populations is primarily for dystonia, notably inherited dystonia without nervous system pathology.(21) In children with refractory disease processes, DBS has been previously utilized for novel indications, such as select cases of Tourette's syndrome, obsessive-compulsive disorder (OCD), and epilepsy with varying levels of success.(22-26) In the course of DBS treatment for dystonia and Tourette's syndrome in adult patients with comorbid SIB, reduction in the frequency or full cessation of SIB has been reported. $(27,28)$ DBS of several targets has previously been employed to treat SIB, including in six patients under the age of 20 with ASD (Table 1). These targets include the basolateral amygdala,(29) globus pallidus internus,(30) posterior hypothalamus (31) and the nucleus accumbens (NAcc).(32) 
Table 1

Literature Review of DBS for the Treatment of SIB \& ASD

\begin{tabular}{|c|c|c|c|c|c|}
\hline (33)Author & $\begin{array}{l}\text { Age, } \\
\text { Sex }\end{array}$ & Behaviour & $\begin{array}{l}\text { DBS Target } \\
\text { (programming) }\end{array}$ & Pre-DBS Score & $\begin{array}{l}\text { Post-DBS } \\
\text { Score }\end{array}$ \\
\hline $\begin{array}{l}\text { Sturm } \\
2012(29)\end{array}$ & $13 \mathrm{M}$ & $\begin{array}{l}\text { Self- } \\
\text { aggression }\end{array}$ & $\begin{array}{l}\text { Basolateral Amygdala } \\
(120 \mu \mathrm{s}, 130 \mathrm{~Hz}, 2-6.5 \mathrm{~V})\end{array}$ & $\begin{array}{l}\text { Restraints do not } \\
\text { prevent skin lesions } \\
\text { and life threatening } \\
\text { self-injury }\end{array}$ & $\begin{array}{l}\text { Restraint of the } \\
\text { wrists suffices } \\
\text { and is well } \\
\text { tolerated }\end{array}$ \\
\hline $\begin{array}{l}\text { Stocco } \\
2014(30)\end{array}$ & $19 F$ & Self-picking & $\begin{array}{l}\text { Globus Pallidus Internus } \\
(120 \mu \mathrm{s}, 80 \mathrm{~Hz}, 3.3 \mathrm{~V})\end{array}$ & JHMRS 46 & JHMRS 4 \\
\hline $\begin{array}{l}\text { Stocco } \\
2014(30)\end{array}$ & $17 \mathrm{M}$ & $\begin{array}{l}\text { Punching of } \\
\text { arms and } \\
\text { legs, biting }\end{array}$ & $\begin{array}{l}\text { Globus Pallidus Internus } \\
(120 \mu \mathrm{s}, 100 \mathrm{~Hz}, 2.5 \mathrm{~V})+ \\
\text { Anterior limb of internal } \\
\text { capsule } \\
(210 \mu \mathrm{s} 100 \mathrm{~Hz} 2.0 \mathrm{~V})\end{array}$ & JHMRS 67 & JHMRS 19 \\
\hline $\begin{array}{l}\text { Benedetti- } \\
\text { Isaac } \\
2015(34)\end{array}$ & $27 \mathrm{M}$ & $\begin{array}{l}\text { Aggressive } \\
\text { behaviour } \\
\text { towards self }\end{array}$ & $\begin{array}{l}\text { Posterior Hypothalamus } \\
(90 \mu \mathrm{s}, 185 \mathrm{~Hz}, 2.7 \mathrm{~V})\end{array}$ & OAS 9 & OAS 1 \\
\hline $\begin{array}{l}\text { Benedetti- } \\
\text { Isaac } \\
2015(34)\end{array}$ & $16 \mathrm{M}$ & $\begin{array}{l}\text { Self- } \\
\text { aggression }\end{array}$ & $\begin{array}{l}\text { Posterior Hypothalamus } \\
(90 \mu \mathrm{s}, 185 \mathrm{~Hz}, 2.8 \mathrm{~V})\end{array}$ & OAS 8 & $\begin{array}{l}\text { OAS } 8 \\
\text { (temporary } \\
\text { improvement } \\
\text { at } 1 \text { month) }\end{array}$ \\
\hline $\begin{array}{l}\text { Segar } \\
2015(35)\end{array}$ & $24 \mathrm{~F}$ & $\begin{array}{l}\text { Biting hands, } \\
\text { picking skin }\end{array}$ & $\begin{array}{l}\text { Nucleus accumbens } \\
(90 \mu \mathrm{s}, 130 \mathrm{~Hz}, 8 \mathrm{~V})\end{array}$ & GAF 20 & GAF 50-60 \\
\hline $\begin{array}{l}\text { Park } 2016 \\
(32)\end{array}$ & $13 \mathrm{M}$ & $\begin{array}{l}\text { Self- } \\
\text { mutilation, } \\
\text { face-hitting } \\
\text { causing } \\
\text { fractures }\end{array}$ & $\begin{array}{l}\text { Nucleus accumbens } \\
(90 \mu \mathrm{s}, 130 \mathrm{~Hz}, 3-5 \mathrm{~V})\end{array}$ & $\begin{array}{l}\text { CGI-S } 6 \\
\text { ABC } 106 \\
\text { CY-BOCS } 22 \\
\text { K-ARS } 54 \\
\text { SRS } 101\end{array}$ & $\begin{array}{l}\text { CGI-S } 4 \\
\text { ABC } 40 \\
\text { CY-BOCS } 7 \\
\text { K-ARS } 36 \\
\text { SRS } 98\end{array}$ \\
\hline $\begin{array}{l}\text { Kakko } \\
2019(33)\end{array}$ & $19 \mathrm{M}$ & $\begin{array}{l}\text { Aggression, } \\
\text { self- } \\
\text { mutilation, } \\
\text { lacerations }\end{array}$ & Globus Pallidus Internus & & $\begin{array}{l}\text { Self-destructive } \\
\text { behaviour } \\
\text { ceased }\end{array}$ \\
\hline $\begin{array}{l}\text { Doshi } \\
2019(36)\end{array}$ & $42 \mathrm{~F}$ & $\begin{array}{l}\text { Hitting, } \\
\text { violent } \\
\text { outbursts }\end{array}$ & $\begin{array}{l}\text { Nucleus accumbens } \\
(60 \mu s, 130 \mathrm{~Hz}, 2.6 \mathrm{~V})\end{array}$ & $\begin{array}{l}\text { YBOCS } 19 \\
\text { HDS } 20 \\
\text { HAS } 30 \\
\text { SCQ } 26\end{array}$ & $\begin{array}{l}\text { YBOCS } 5 \\
\text { HDS } 15 \\
\text { HAS } 18 \\
\text { SCQ } 16\end{array}$ \\
\hline $\begin{array}{l}\text { ABC, Antece } \\
\text { Yale-Brown } \\
\text { functioning; } \\
\text { stereotypy r } \\
\text { Communica }\end{array}$ & $\begin{array}{l}\text { ess } \\
\text { S, } 1 \\
\text { g S } \\
\text { Q }\end{array}$ & $\begin{array}{l}\text { iour Conseq } \\
\text { Compulsive } \\
\text { ilton Anxiety } \\
\text { K-ARS, Kore } \\
\text { ionnaire; SRS }\end{array}$ & $\begin{array}{l}\text { ce; CGI-S, Clinical Globa } \\
\text { e; DBS, deep brain stimı } \\
\text { le; HDS, Hamilton Depre } \\
\text { ADHD Rating Scale; OAS } \\
\text { cial Responsiveness Sc }\end{array}$ & $\begin{array}{l}\text { irment-Severity; CY- } \\
\text {; GAF, global asses } \\
\text { Scale; JHMRS, Joh } \\
\text { t Aggression Scale; }\end{array}$ & $\begin{array}{l}\text { S, Children's } \\
\text { ht of } \\
\text { topkins motor } \\
\text { Social }\end{array}$ \\
\hline
\end{tabular}


The NAcc of the ventral striatum receives projections from the orbitofrontal cortex and sends hierarchical information via spiraling striatonigrostriatal projections to the dorsal striatum. $(37,38)$ Volumetric studies of the striatum suggest that an imbalance of the ventral-dorsal striatal circuity may underlie SIB. $(39,40)$ Likewise, the amygdala, a previous target for SIB in children also projects widely to the striatum, with weaker connectivity patterns in children with ASD.(41) The NAcc also possesses widespread projections to the dopaminergic receptors of the ventral tegmental area.(37) Other pathologies, such as OCD, addiction and alcoholism, have been treated with NAcc-DBS.(42-45) When the NAcc is targeted for DBS, the anterior limb of the internal capsule (ALIC) can be stimulated simultaneously to augment behavioural changes related to attention and sensorimotor control.

\section{Study Design}

We present a protocol for a single-center, single-cohort, open-label, non-randomized prospective pilot trial of NAcc-DBS for refractory and severe SIB in children with ASD. The trial is currently open for recruitment at the Hospital for Sick Children (HSC) in Toronto.

\section{Goals and Objectives}

The primary objective of the study is to assess feasibility and safety, measured by recruitment rate, identification of factors impacting follow-up and protocol adherence, and successful implantation. Secondary objectives include change in frequency or severity of SIB following surgery, measured regularly by caregiver-reported questionnaires over the course of one year. Additional clinical outcomes include changes quality of life for the patient and their caregiver(s), repetitive motion characteristics as measured with actigraphy, metabolic changes seen through positron emission tomography (PET), and changes on electrophysiologic data. This is the first prospective trial of DBS for children with SIB and represents the first assessment of a potential surgical treatment for patients with extremely limited therapeutic options.

\section{Methods/design}

This is a prospective, single-center, open-label, non-randomized study of six patients at HSC. The aim is to evaluate the feasibility and safety of DBS of the NAcc for medically-refractory, repetitive self-injurious behaviours in children with ASD. Electrophysiological parameters are optimized in the 12-month follow-up to study and manage possible side effects.

\section{Ethics \& Registry}

This research involves human participants and is performed in accordance with the Delcaration of Helsinki. This trial was approved by the Hospital for Sick Children Research Ethics Board, approval number 1000060282. Registration on ClinicalTrials.gov was completed in June of 2019 with the Identifier: NCT03982888. Patient recruitment and continuation in the study is considered by a safety monitoring board at HSC. Written informed consent to participate in the trial is acquired from the child or adolescent when able, or the parent or legal guardians. If the child or adolescent is unable to provide consent, assent is sought. 
Potential participants are recruited from specialized behavioural clinics. Potential

participants are reviewed by the investigators with respect to inclusion and exclusion criteria

(Table 2). Eligible patients are discussed in a multidisciplinary meeting of the surgical, psychiatric and medical teams. There are no changes to the participants' medications or behaviour therapies after enrollment prior to surgery. Any changes to medications following surgery are noted, including changes to dosages and indication for change.

\section{Table 2: Study Inclusion \& Exclusion Criteria}

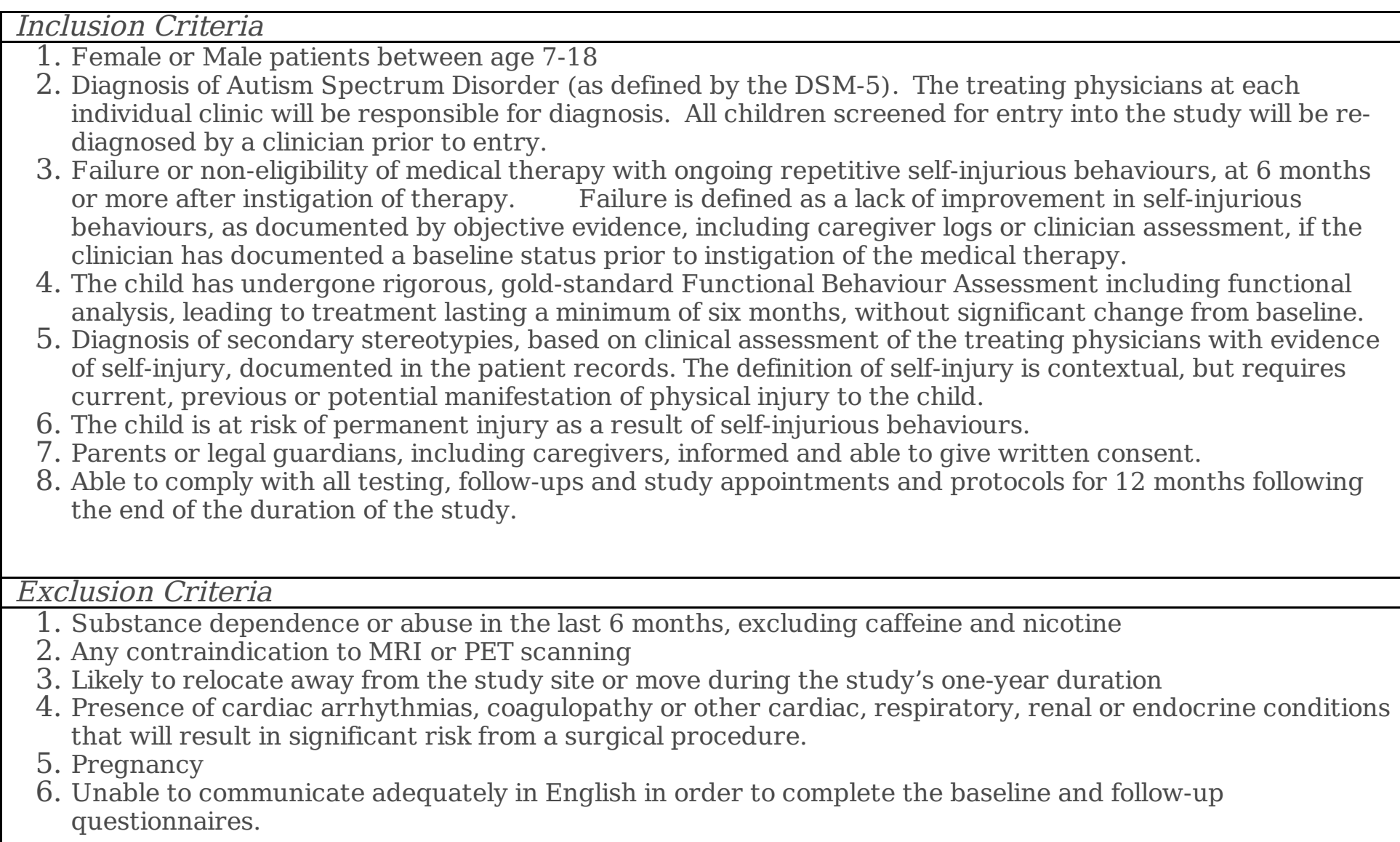

Participants are assessed by the anesthesia service, neuropsychology team, and receive a magnetic resonance image (MRI) and optional fluorodeoxyglucose (FDG) PET scan. On the day of surgery, a Leksell stereotactic frame is applied under general anesthesia. The patient receives a head computed tomography (CT) scan that is merged to the pre-operative MRI and planned targets. Stereotactic coordinates are calculated and verified to target the NAcc with the goal to include the ALIC in the trajectory of the DBS electrode (Figure 1B\&C). In the operating room, a curvilinear incision anterior to the coronal suture is made to place the DBS electrodes stereotactically. Thresholds for side effects are recorded intraoperatively. Electrodes 
are placed with fluoroscopic confirmation and a pulse generator is connected and implanted in the infraclavicular region under the same anesthetic.

Patients undergo a postoperative MRI to confirm the position of the electrodes. After the surgery, they are monitored in the hospital for 3-5 days and discharged with the stimulator off. Patients start DBS programming at 4-6 weeks after surgery and visit the joint neurosurgery, neurology DBS clinic at HSC. There is regular monitoring for the development of behavioural, motor, and psychiatric effects from stimulation. During weeks 2-6, there are weekly follow-ups to address any potential complications. The full schedule of events is presented in Table 3.

\section{Sample Size and Recruitment}

In this prospective, controlled trial, six patients are selected to determine safety and initial efficacy, as it typical for most DBS early phase trials. There is no control group, and each patient will serve as a comparator for primary outcome measures. 


\begin{tabular}{|c|c|c|c|c|c|c|c|c|c|}
\hline & \multicolumn{7}{|c|}{ Study Period } & \multirow{4}{*}{$\begin{array}{l}\text { Post- } \\
\text { Trial } \\
\mathrm{W}>52\end{array}$} \\
\hline & & \multirow{2}{*}{$\begin{array}{c}\text { Enrollment } \\
\text { Week }-8 \\
+/-4 \text { weeks }\end{array}$} & \multirow{2}{*}{$\begin{array}{l}\text { Surgery } \\
\text { Baseline } \\
\text { w0 }\end{array}$} & \multicolumn{5}{|c|}{ Follow-up } & \\
\hline \multicolumn{2}{|c|}{ Timepoint } & & & Weekly & Every 4 & & & & \\
\hline \multirow[t]{5}{*}{ irollment } & Eligibility screen & $\mathrm{X}$ & & & & & & & \\
\hline & $\begin{array}{r}\text { Informed } \\
\text { Consent for Trial } \\
\end{array}$ & $\mathrm{X}$ & & & & & & & \\
\hline & $\begin{array}{l}\text { Demographics } \\
\text { Questionnaire }\end{array}$ & $\mathrm{X}$ & & & & & & & \\
\hline & $\begin{array}{l}\text { Anesthetic } \\
\text { Evaluation }\end{array}$ & $\mathbf{X}$ & & & & & & & \\
\hline & $\begin{array}{r}\text { Informed } \\
\text { Surgical Consent }\end{array}$ & $\mathbf{X}$ & & & & & & & \\
\hline \multirow[t]{2}{*}{$\begin{array}{l}\text {-Hospital } \\
\text { :atment \& } \\
\text { Care }\end{array}$} & $\begin{array}{r}\text { Deep Brain } \\
\text { Stimulation } \\
\text { leads and IPG } \\
\text { insertion } \\
\end{array}$ & & $\mathbf{X}$ & & & & & & \\
\hline & Programming & & & & $\mathbf{X}$ & $\bar{X}$ & $\mathbf{X}$ & $\mathbf{X}$ & $\begin{array}{c}\text { Every } 6 \\
\text { months } \\
\text { or as } \\
\text { indicated } \\
\end{array}$ \\
\hline \multirow{3}{*}{ maging } & MRI & $\mathrm{X}$ (or earlier) & $\mathbf{X}$ & & & & & & \\
\hline & $\mathrm{CT}$ & & $\mathbf{X}$ & & & & & & \\
\hline & $\begin{array}{r}\text { FDG-PET } \\
\text { (optional) }\end{array}$ & $\mathrm{X}$ & & & & & & $\mathrm{X}$ & \\
\hline \multirow[t]{6}{*}{ stionnaires } & $\begin{array}{r}\text { Children's Yale- } \\
\text { Brown } \\
\text { Obsessive- } \\
\text { Compulsive } \\
\text { Scale (CY- } \\
\text { BOCS) }\end{array}$ & $\mathrm{X}$ & & & & $\mathrm{X}$ & $\mathrm{X}$ & $\mathrm{X}$ & \\
\hline & $\begin{array}{r}\text { Inventory of } \\
\text { Statements } \\
\text { about Self-Injury } \\
\text { (ISAS) }\end{array}$ & $\mathrm{X}$ & & & & $\mathrm{X}$ & $\mathrm{X}$ & $\mathrm{X}$ & \\
\hline & $\begin{array}{r}\text { Behavior } \\
\text { Problems } \\
\text { Inventory (BPI) } \\
\end{array}$ & $\mathrm{X}$ & & & & $\mathrm{X}$ & $\mathrm{X}$ & $\mathrm{X}$ & \\
\hline & $\begin{array}{r}\text { Repetitive } \\
\text { Behaviour Scale- } \\
\text { Revised (RBS-R) }\end{array}$ & $\mathrm{X}$ & & & & $\mathrm{X}$ & $\mathrm{X}$ & $\mathrm{X}$ & \\
\hline & $\begin{array}{r}\text { Quality of Life } \\
\text { Scale 9Peds QL }\end{array}$ & $\mathrm{X}$ & & & & $\mathrm{X}$ & $\mathrm{X}$ & $\mathrm{X}$ & \\
\hline & $\begin{array}{r}\text { Aberrant } \\
\text { Behaviour } \\
\text { Checklist } \\
\end{array}$ & $\mathrm{X}$ & & & & $\mathrm{X}$ & $\mathrm{X}$ & $\mathrm{X}$ & \\
\hline \multirow[t]{4}{*}{$\begin{array}{l}\text { Other } \\
\text {;essments }\end{array}$} & $\begin{array}{c}\text { Neurosurgery } \\
\text { Evaluation } \\
\end{array}$ & & & $\begin{array}{c}\mathrm{X} \\
\text { (virtual) } \\
\end{array}$ & $\begin{array}{c}\mathrm{X} \\
\text { (virtual) } \\
\end{array}$ & $\mathbf{X}$ & $\mathbf{X}$ & $\mathbf{X}$ & $\begin{array}{l}\text { Annual } \\
\text { follow-up }\end{array}$ \\
\hline & $\begin{array}{r}\text { Neuropsychology } \\
\text { Evaluation }\end{array}$ & $\mathbf{X}$ & & & & & $\bar{X}$ & $\mathrm{X}$ & $\begin{array}{c}\text { As } \\
\text { needed }\end{array}$ \\
\hline & $\begin{array}{r}\text { Actigraphy } \\
\text { (Optional) } \\
\end{array}$ & $\mathrm{X}$ & & & & $\mathrm{X}$ & & $\mathrm{X}$ & \\
\hline & Self-Injury Log & $\mathrm{X}$ & & $\mathrm{X}$ & $\mathrm{X}$ & $\mathrm{X}$ & $\mathrm{X}$ & $\mathrm{X}$ & \\
\hline
\end{tabular}

Table 3: Follow-up Schedule for trial participants. Bolded cells show standard of care for all pediatric DBS patients. 
Fea sibility and Safety

The trial will be determined feasible if there is $>20 \%$ recruitment rate. This will provide additional information regarding decision-making for experimental surgical trials. Any deviance to study protocol or inability to complete clinical questionnaires will be documented with an attempt to understand patient barriers.

Safety of the intervention will be carefully monitored with weekly phone calls to participants for the first six weeks. Parents are cautioned and reminded about the signs of infection or sudden changes in neurologic function prior to discharge from hospital.

\section{Clinical Outcome Measures}

This trial will conduct pre-post analyses to compare frequency and severity of SIB in children and youth with ASD before and after DBS intervention. Clinical outcomes are measured by the change between baseline and 1-year in the following scales: Children's Yale-Brown Obsessive-Compulsive Scale (CY-BOCS), $(46,47)$ the Behavior Problems Inventory (BPI), (48) the Inventory of Statements about Self-Injury (ISAS) (49) and the Repetitive Behaviour Scale-Revised (RBS-R).(50) Secondary clinical outcomes are measured using the Quality of Life Scale 9Peds QL version 4, Aberrant Behaviour Checklist, $(51,52)$ and caregiver logs of repetitive self-injurious behaviours.

Patients and caregivers complete scales prior to the intervention and also at week 12, week 26, and week 52. Baseline assessments are completed prior to surgery. Efficacy is determined by the within-subject percent change in the primary outcome scores at 1 year (week 52) following surgery compared to baseline.

Additional outcomes include changes in motor patterns based on actigraphy. Actigraphy is the continuous measurement of an individuals' movement using a device worn similarly to a watch (Axivity AX3 and Axivity AX6).(53,54) The Axivity device can quantify movements and has been validated to detect specific behaviours, such as hand flapping, of patients with ASD with 94.6\% accuracy.(55) Children have an actigraph placed on their nondominant wrist 4 weeks prior to the surgery for a total of 2 weeks of recordings. During specific follow-up visits (weeks 12, 26, and 52), the children have the option to wear the actigraph for 2-week intervals. Markers of stereotypies include maximum and minimum value amplitudes, variance, peak to peak, and entropy fast fourier transform, to be analyzed using MATLAB (Mathworks, Natick, MA).(53, 55)

Children enrolled in the trial may receive a FDG-PET scan prior to surgery, and 12 months after surgery. PET scanning is optional and for research purposes only, which will be disclosed to 
all participants. PET scans of pediatric patients with anorexia who received NAcc-DBS has demonstrated the reversal of metabolic abnormalities, such as hypermetabolism in the frontal lobes, hippocampus, and lentiform nucleus.(56) The FDG-PET of participants in the present study may similarly demonstrate changes of metabolism in the brain following NAcc-DBS.

Follow-up

Evaluation and assessments occur at approximately 22 time points from pre- to 1-year post-surgery (Table 3). Participants are followed weekly after surgery by the medical team between weeks 0-6, and monthly after 8 weeks. There are two required MRI scans that fall under the standard of care, two optional FDG-PET scans, and 3 possible two-week periods of actigraph recordings. Surveys for the primary clinical outcomes and secondary outcomes are administered once prior to the surgery and three times following surgery. DBS programming starts at approximately 4-6 weeks and reassessment and stimulation changes are planned for weeks 12,26 , and 52 unless there are adverse effects, for which there will be additional programming visits. Ongoing follow-up for safety and DBS programming will occur at HSC until participants turn 18 years old, at which point they will be transitioned to adult care.

\section{Data Management \& Statistical Analysis}

Patient information will be kept strictly confidential at all times, and all files related to this study will be password protected and kept on a password protected computer. Patient and caregivers will complete surveys and questionnaires online via a secure email link or on paper. The research team will check the content and completion of the forms monthly. All data will be kept for 25 years following the conclusion of the trial.

This is not a blinded study and all investigators and patients are aware of treatment. There is not blinded stimulation-off or stimulation-on periods after DBS implantation. Change in SIB and adverse effects will be analyzed longitudinally using comparative statistics. Repeated measures ANOVA and mixed-effects linear regression are used for analysis of clinical measures and changes over the course of 12 months. All efforts are made to reduce missing data with retrospective review and multiple imputation will be employed for unfound data.

\section{Discussion}

The current paper presents a single-cohort, open-label, non-randomized, prospective pilot trial for the first controlled study of DBS of the NAcc for severe, refractory SIB in children and youth with ASD. This study is 
important to understand treatment response and safety as well as unforeseen barriers to recruitment and followup.

SIB has a high prevalence in several genetic disorders, such as Lesch-Nyhan disease and Fragile X syndrome, suggesting the pathophysiology of SIB may at least in part be rooted in neurobiological as well as neurodevelopmental etiologies.(6) Conversely, environmental triggers, such as novel sensory stimuli or changes in routine, often trigger the onset of episodes of SIB.(57) In patients with ASD, SIB frequency has a direct correlation with ASD severity.(58) The phenotype of SIB in patients with ASD shares similar features to phenotypic behaviours in other psychiatric conditions affecting children and adults, including OCD, attentiondeficit hyperactivity disorder, and Tourette's syndrome.(59) These conditions may be comorbid and share a common behavioural phenotype characterized by repetition, rigidity, invariance and sometimes inappropriateness. $(39,59)$ Improved understanding of neural circuitry and effective DBS treatment options for one indication may enrich the understanding of the related diagnoses and their neurobiological pathophysiology.

DBS is a minimally invasive surgical option for patients with refractory SIB. It is reversible, adjustable and has a well-tolerated safety profile. Although increasingly offered to children for expanding indications, it is often considered an experimental therapy in this context. A proposed ethical framework to guide the conduct of DBS in children has been proposed, to which this study adheres.(60) The principles of this framework include viewing outcomes in a developmentally relevant context, cautiously applying adult data, and weighing the timing of the procedure.(60)

Adult data and experience regarding DBS are not directly applicable to children. As one example, most children will have surgery under general anesthesia, which may preclude microelectrode recordings. Second, stimulation settings are often adopted from adult literature, yet long-term effects for children are not yet fully understood.(23) Third, indications and decisions regarding timing for intervention are complicated in children as treatment decisions are made within the context of childhood development and disease natural history. For example, the natural history of Tourette's syndrome is often to remit as children develop and therefore the indications for DBS in children are as-of-yet unknown. $(61,62)$ Finally, complications including infection, lead migration or wire fractures are probably higher in children,(21) and side effects of DBS on the developing brain require further study. Moreover, these hardware-related adverse events may manifest differently in children and youth with ASD and repetitive or compulsive SIB, relative to other pediatric cohorts.

\section{Strengths and limitations}

This is a prospective, pilot trial of six patients and analyses of clinical outcomes will be limited by the small cohort. The results of this trial should inform larger clinical trials of multiple institutions. Furthermore, there is a lack of consensus regarding the ideal clinical assessment tool to measure the severity and frequency of SIB events. The use of the CY-BOCS, ISAS and the RBS-R questionnaires incorporates several aspects of SIB such as repetitive movements, degree of harm, and impact on functional activities.

\section{Conclusion}

This trial has primary objectives to assess the feasibility and safety of DBS for SIB in children with ASD. Clinical outcomes are composed of the change in CY-BOCS, ISAS and the RBS-R questionnaires. Additional outcomes 
include measures of participant and caregiver quality of life, actigraph measurements, PET changes, and electrophysiologic data. These data will inform the design and conduct of future investigations in this vulnerable population to deliver novel effective therapies.

\section{List Of Abbrevations}

ALIC

ASD

CGI-S

CT

CY-BOCS

DBS

DSM-V

FDG

GAF

HAS

HDS

HSC

ISAS

JHMRS

K-ARS

MRI

NAcc

OAS

OCD

PET

RBS-R

SCQ anterior limb of internal capsule

autism spectrum disorder

Clinical Global Impairment-Severity

computed tomography

Children's Yale-Brown Obsessive-Compulsive Scale

deep brain stimulation

Diagnostic and Statistical Manual of Mental Disorders, $5^{\text {th }}$ edition

flurodeoxyglucose

global assessment of functioning

Hamilton Anxiety Scale

Hamilton Depression Scale

Hospital for Sick Children

Inventory of Statements about Self-Injury

John's Hopkins motor stereotypy rating scale

Korean ADHD Rating Scale

magnetic resonance image

nucleus accumbens

Overt Aggression Scale

obsessive-compulsive disorder

positron emission tomography

Repetitive Behavioural Scale-Revised

Social Communication Questionnaire 


\section{Declarations}

Ethics approval and consent to participate

- This trial was approved by the Research Ethics Board at the Hospital of Sick Children, with protocol number 1000060282.

- Consent to participate in the trial is acquired from parent or legal guardians and assent is sought from the child or adolescent.

Consent for publication

- Not applicable

Availability of data and materials

- The datasets generated and/or analysed during the current study are not publicly available due to patient privacy given the small cohort but are available from the corresponding author on reasonable request.

Competing interests

- F. is a consultant for Abbott, Ceregate, Ipsen, Medtronic, Boston Scientific, and AbbVie Inc. He has received research support from Medtronic, Boston Scientific, University of Toronto, Michael J. Fox Foundation for Parkinson's Research, Dystonia Medical Research Foundation, and honoraria for serving as a speaker from Abbott, UCB, Medtronic, Paladin, Sunovion, Ipsen, Boston Scientific, AbbVie Inc.

- There are no other declarations of COI.

Funding

- Not applicable

Authors' contributions

- This study was conceived by GMI, with clinical implementation by SB, CG, AF, AR and AL.

- The manuscript was written by HY, with significant contributions by LS, SB, AR, AL and AVK.

- Inclusion criteria and selection of outcome measures influenced by GMI, HY, AR, AL, AVK

- All authors read and approved the final manuscript.

Funding

- Not applicable

Acknowledgements 
- Not applicable

\section{References}

1. Lobar SL. DSM-V Changes for Autism Spectrum Disorder (ASD). Implications for Diagnosis, Management, and Care Coordination for Children With ASDs. J Pediatr Health Care. 2016;30(4):359-65.

2. Lai MC, Lombardo MV, Baron-Cohen S. Autism Lancet. 2014;383(9920):896-910.

3. Lai MC, Lombardo MV, Auyeung B, Chakrabarti B, Baron-Cohen S. Sex/gender differences and autism: setting the scene for future research. J Am Acad Child Adolesc Psychiatry. 2015;54(1):11-24.

4. Venker CE, Ray-Subramanian CE, Bolt DM, Ellis Weismer S. Trajectories of autism severity in early childhood. J Autism Dev Disord. 2014;44(3):546-63.

5. Adler BA, Wink LK, Early M, Shaffer R, Minshawi N, McDougle CJ, et al. Drug-refractory aggression, selfinjurious behavior, and severe tantrums in autism spectrum disorders: a chart review study. Autism. 2015;19(1):102-6.

6. Huisman S, Mulder P, Kuijk J, Kerstholt M, van Eeghen A, Leenders A, et al. Self-injurious behavior. Neurosci Biobehav Rev. 2018;84:483-91.

7. Baghdadli A, Pascal C, Grisi S, Aussilloux C. Risk factors for self-injurious behaviours among 222 young children with autistic disorders. J Intellect Disabil Res. 2003;47(Pt 8):622-7.

8. Sinha S, McGovern RA, Sheth SA. Deep brain stimulation for severe autism: from pathophysiology to procedure. Neurosurg Focus. 2015;38(6):E3.

9. Boser K, Higgins S, Fetherston A, Preissler MA, Gordon B. Semantic fields in low-functioning autism. J Autism Dev Disord. 2002;32(6):563-82.

10. Bradley V, Hiersteiner D, Rotholz D, Maloney J, Li H, Bonardi A, et al. Personal characteristics and outcomes of individuals with developmental disabilities who need support for self-injurious behaviour. J Intellect Disabil Res. 2018;62(12):1043-57.

11. Le JF, Lohr WD. Aggression and self-injury in a patient with severe autism. Pediatr Ann. 2012;41(10):1-3.

12. Hagopian LP, Rooker GW, Zarcone JR. Delineating subtypes of self-injurious behavior maintained by automatic reinforcement. J Appl Behav Anal. 2015;48(3):523-43.

13. Malone RP, Waheed A. The role of antipsychotics in the management of behavioural symptoms in children and adolescents with autism. Drugs. 2009;69(5):535-48.

14. Sabus A, Feinstein J, Romani P, Goldson E, Blackmer A. Management of Self-injurious Behaviors in Children with Neurodevelopmental Disorders: A Pharmacotherapy Overview. Pharmacotherapy. 2019;39(6):645-64.

15. Ricketts RW, Goza AB, Ellis CR, Singh YN, Singh NN, Cooke JC 3. Fluoxetine treatment of severe self-injury in young adults with mental retardation. J Am Acad Child Adolesc Psychiatry. 1993;32(4):865-9. rd. .

16. McCracken JT, McGough J, Shah B, Cronin P, Hong D, Aman MG, et al. Risperidone in children with autism and serious behavioral problems. N Engl J Med. 2002;347(5):314-21.

17. Lucchelli JP, Bertschy G. Low-Dose Fluoxetine in Four Children with Autistic Spectrum Disorder Improves Self-Injurious Behavior, ADHD-Like Symptoms, and Irritability. Case Rep Psychiatry. 2018;2018:6278501.

18. Iwata BA, Dorsey MF, Slifer KJ, Bauman KE, Richman GS. Toward a functional analysis of self-injury. J Appl Behav Anal. 1994;27(2):197-209. 
19. Hagopian LP, Rooker GW, Zarcone JR, Bonner AC, Arevalo AR. Further analysis of subtypes of automatically reinforced SIB: A replication and quantitative analysis of published datasets. J Appl Behav Anal. 2017;50(1):48-66.

20. Miocinovic S, Somayajula S, Chitnis S, Vitek JL. History, applications, and mechanisms of deep brain stimulation. JAMA Neurol. 2013;70(2):163-71.

21. Elkaim LM, Alotaibi NM, Sigal A, Alotaibi HM, Lipsman N, Kalia SK, et al. Deep brain stimulation for pediatric dystonia: a meta-analysis with individual participant data. Dev Med Child Neurol. 2019;61(1):49-56.

22. Valentin A, Selway RP, Amarouche M, Mundil N, Ughratdar I, Ayoubian L, et al. Intracranial stimulation for children with epilepsy. Eur J Paediatr Neurol. 2017;21(1):223-31.

23. Marks WA, Honeycutt J, Acosta F, Reed M. Deep brain stimulation for pediatric movement disorders. Semin Pediatr Neurol. 2009;16(2):90-8.

24. Yan H, Toyota E, Anderson M, Abel TJ, Donner E, Kalia SK, et al. A systematic review of deep brain stimulation for the treatment of drug-resistant epilepsy in childhood. J Neurosurg Pediatr. 2018;23(3):27484.

25. Testini P, Min HK, Bashir A, Lee KH. Deep Brain Stimulation for Tourette's Syndrome: The Case for Targeting the Thalamic Centromedian-Parafascicular Complex. Front Neurol. 2016;7:193.

26. Duarte-Batista P, Coelho M, Quintas S, Levy P, Castro Caldas A, Goncalves-Ferreira A, et al. Anterior Limb of Internal Capsule and Bed Nucleus of Stria Terminalis Stimulation for Gilles de la Tourette Syndrome with Obsessive-Compulsive Disorder in Adolescence: A Case of Success. Stereotact Funct Neurosurg. 2020;98(2):95-103.

27. Cif L, Biolsi B, Gavarini S, Saux A, Robles SG, Tancu C, et al. Antero-ventral internal pallidum stimulation improves behavioral disorders in Lesch-Nyhan disease. Mov Disord. 2007;22(14):2126-9.

28. Houeto JL, Karachi C, Mallet L, Pillon B, Yelnik J, Mesnage V, et al. Tourette's syndrome and deep brain stimulation. J Neurol Neurosurg Psychiatry. 2005;76(7):992-5.

29. Sturm V, Fricke O, Buhrle CP, Lenartz D, Maarouf M, Treuer H, et al. DBS in the basolateral amygdala improves symptoms of autism and related self-injurious behavior: a case report and hypothesis on the pathogenesis of the disorder. Front Hum Neurosci. 2012;6:341.

30. Stocco A, Baizabal-Carvallo JF. Deep brain stimulation for severe secondary stereotypies. Parkinsonism Relat Disord. 2014;20(9):1035-6.

31. Benedetti-Isaac JC, Torres-Zambrano M, Vargas-Toscano A, Perea-Castro E, Alcala-Cerra G, Furlanetti LL, et al. Seizure frequency reduction after posteromedial hypothalamus deep brain stimulation in drug-resistant epilepsy associated with intractable aggressive behavior. Epilepsia. 2015;56(7):1152-61.

32. Park HR, Kim IH, Kang H, Lee DS, Kim BN, Kim DG, et al. Nucleus accumbens deep brain stimulation for a patient with self-injurious behavior and autism spectrum disorder: functional and structural changes of the brain: report of a case and review of literature. Acta Neurochir (Wien). 2017;159(1):137-43.

33. Kakko K, Bjelogrlic-Laakso N, Pihlakoski L, Lehtimaki K, Jarventausta K. Tardive Dyskinesia Should Not Be Overlooked. J Child Adolesc Psychopharmacol. 2019;29(1):72-4.

34. Benedetti-Isaac JC, Torres-Zambrano M, Vargas-Toscano A, Perea-Castro E, Alcala-Cerra G, Furlanetti LL, et al. Seizure frequency reduction after posteromedial hypothalamus deep brain stimulation in drug-resistant epilepsy associated with intractable aggressive behavior. Epilepsia. 2015;56(7):1152-61. 
35. Segar DJ, Chodakiewitz YG, Torabi R, Cosgrove GR. Deep brain stimulation for the obsessive-compulsive and Tourette-like symptoms of Kleefstra syndrome. Neurosurg Focus. 2015;38(6):E12.

36. Doshi PK, Hegde A, Desai A. Nucleus Accumbens Deep Brain Stimulation for Obsessive-Compulsive Disorder and Aggression in an Autistic Patient: A Case Report and Hypothesis of the Role of Nucleus Accumbens in Autism and Comorbid Symptoms. World Neurosurg. 2019;125:387-91.

37. Watabe-Uchida M, Zhu L, Ogawa SK, Vamanrao A, Uchida N. Whole-brain mapping of direct inputs to midbrain dopamine neurons. Neuron. 2012;74(5):858-73.

38. Haber SN, Fudge JL, McFarland NR. Striatonigrostriatal pathways in primates form an ascending spiral from the shell to the dorsolateral striatum. J Neurosci. 2000;20(6):2369-82.

39. Langen M, Bos D, Noordermeer SD, Nederveen $H$, van Engeland H, Durston S. Changes in the development of striatum are involved in repetitive behavior in autism. Biol Psychiatry. 2014;76(5):405-11.

40. Cauda F, Geda E, Sacco K, D'Agata F, Duca S, Geminiani G, et al. Grey matter abnormality in autism spectrum disorder: an activation likelihood estimation meta-analysis study. J Neurol Neurosurg Psychiatry. 2011;82(12):1304-13.

41. Shen MD, Li DD, Keown CL, Lee A, Johnson RT, Angkustsiri K, et al. Functional Connectivity of the Amygdala Is Disrupted in Preschool-Aged Children With Autism Spectrum Disorder. J Am Acad Child Adolesc Psychiatry. 2016;55(9):817-24.

42. Ho AL, Salib AN, Pendharkar AV, Sussman ES, Giardino WJ, Halpern CH. The nucleus accumbens and alcoholism: a target for deep brain stimulation. Neurosurg Focus. 2018;45(2):E12.

43. Wilden JA, Qing KY, Hauser SR, McBride WJ, Irazoqui PP, Rodd ZA. Reduced ethanol consumption by alcoholpreferring $(P)$ rats following pharmacological silencing and deep brain stimulation of the nucleus accumbens shell. J Neurosurg. 2014;120(4):997-1005.

44. Islam L, Franzini A, Messina G, Scarone S, Gambini O. Deep brain stimulation of the nucleus accumbens and bed nucleus of stria terminalis for obsessive-compulsive disorder: a case series. World Neurosurg. 2015;83(4):657-63.

45. Vannemreddy P, Slavin K. Nucleus Accumbens as a Novel Target for Deep Brain Stimulation in the Treatment of Addiction: A Hypothesis on the Neurochemical and Morphological Basis. Neurol India. 2019;67(5):12204.

46. Goodman WK, Price LH, Rasmussen SA, Mazure C, Fleischmann RL, Hill CL, et al. The Yale-Brown Obsessive Compulsive Scale. I. Development, use, and reliability. Arch Gen Psychiatry. 1989;46(11):1006-11.

47. Goodman WK, Price LH, Rasmussen SA, Mazure C, Delgado P, Heninger GR, et al. The Yale-Brown Obsessive Compulsive Scale. II. Validity. Arch Gen Psychiatry. 1989;46(11):1012-6.

48. Rojahn J, Matson JL, Lott D, Esbensen AJ, Smalls Y. The Behavior Problems Inventory: an instrument for the assessment of self-injury, stereotyped behavior, and aggression/destruction in individuals with developmental disabilities. J Autism Dev Disord. 2001;31(6):577-88.

49. Klonsky ED, Olino TM. Identifying clinically distinct subgroups of self-injurers among young adults: a latent class analysis. J Consult Clin Psychol. 2008;76(1):22-7.

50. Bodfish JW, Symons FJ, Parker DE, Lewis MH. Varieties of repetitive behavior in autism: comparisons to mental retardation. J Autism Dev Disord. 2000;30(3):237-43. 
51. Aman MG, Singh NN, Stewart AW, Field CJ. Psychometric characteristics of the aberrant behavior checklist. Am J Ment Defic. 1985;89(5):492-502.

52. Aman MG, Singh NN, Stewart AW, Field CJ. The aberrant behavior checklist: a behavior rating scale for the assessment of treatment effects. Am J Ment Defic. 1985;89(5):485-91.

53. Min $\mathrm{CH}$, Tewfik AH. Automatic characterization and detection of behavioral patterns using linear predictive coding of accelerometer sensor data. Conf Proc IEEE Eng Med Biol Soc. 2010;2010:220-3.

54. Doherty A, Jackson D, Hammerla N, Plotz T, Olivier P, Granat MH, et al. Large Scale Population Assessment of Physical Activity Using Wrist Worn Accelerometers: The UK Biobank Study. PLoS One. 2017;12(2):e0169649.

55. Amiri AM, Peltier N, Goldberg C, Sun Y, Nathan A, Hiremath SV, et al. WearSense: Detecting Autism Stereotypic Behaviors through Smartwatches. Healthcare (Basel). 2017;5(1).

56. Zhang HW, Li DY, Zhao J, Guan YH, Sun BM, Zuo CT. Metabolic imaging of deep brain stimulation in anorexia nervosa: a 18F-FDG PET/CT study. Clin Nucl Med. 2013;38(12):943-8.

57. Bronsard G, Botbol M, Tordjman S. Aggression in low functioning children and adolescents with autistic disorder. PLoS One. 2010;5(12):e14358.

58. Goldman S, Wang C, Salgado MW, Greene PE, Kim M, Rapin I. Motor stereotypies in children with autism and other developmental disorders. Dev Med Child Neurol. 2009;51(1):30-8.

59. Langen M, Durston S, Kas MJ, van Engeland H, Staal WG. The neurobiology of repetitive behavior: ... and men. Neurosci Biobehav Rev. 2011;35(3):356-65.

60. Davidson B, Elkaim LM, Lipsman N, Ibrahim GM. Editorial. An ethical framework for deep brain stimulation in children. Neurosurg Focus. 2018;45(3):E11.

61. Dowd RS, Pourfar M, Mogilner AY. Deep brain stimulation for Tourette syndrome: a single-center series. J Neurosurg. 2018;128(2):596-604.

62. Servello D, Porta M, Sassi M, Brambilla A, Robertson MM. Deep brain stimulation in 18 patients with severe Gilles de la Tourette syndrome refractory to treatment: the surgery and stimulation. J Neurol Neurosurg Psychiatry. 2008;79(2):136-42.

\section{Figures}



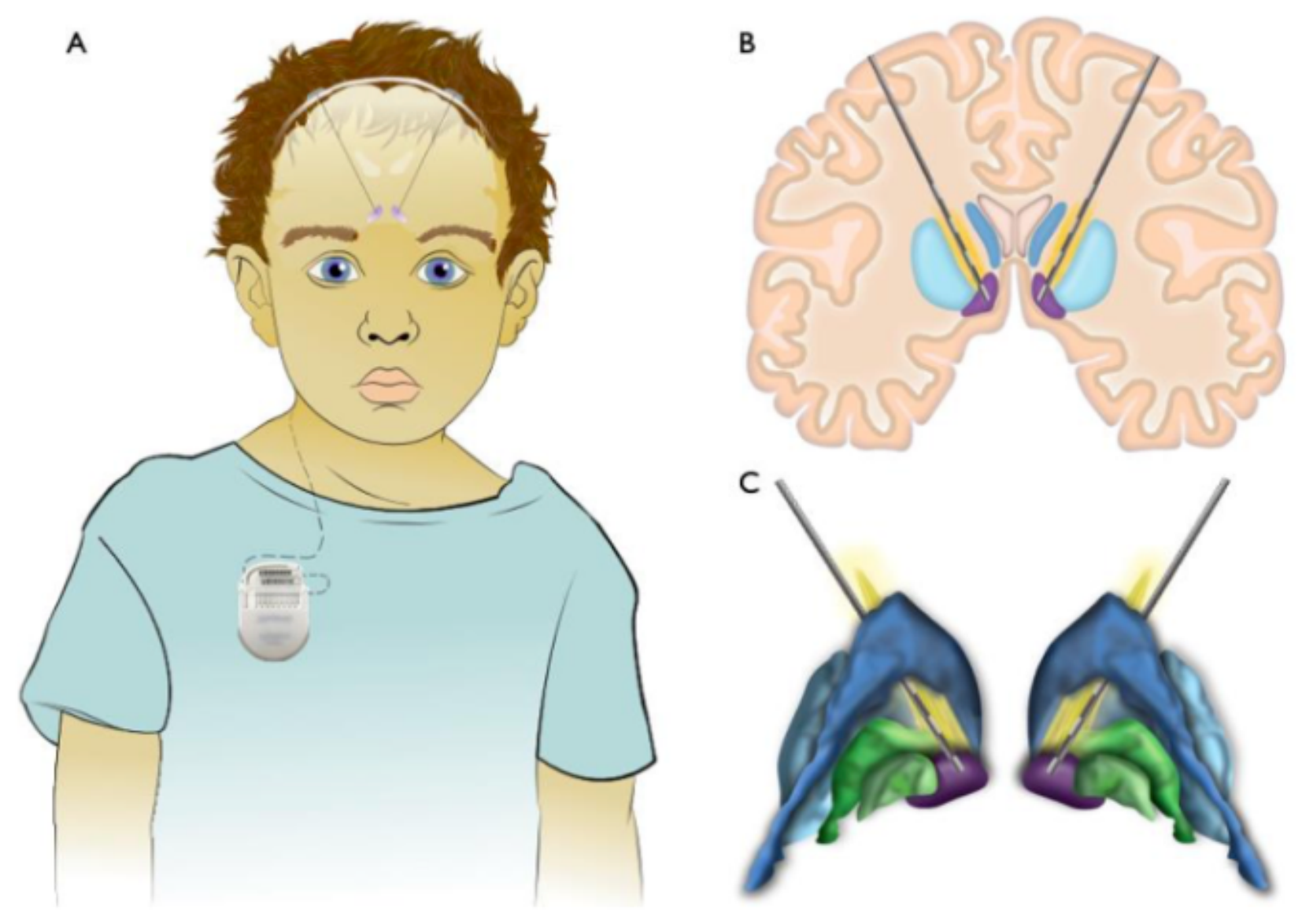

\section{Figure 1}

DBS for children, targeting the NAcc. A: DBS extension wires for children are placed with greater length to allow for growth. B: Coronal representation of DBS lead trajectory, passing through the ALIC and targeting the NAcc. C: 3D representation of DBS lead trajectory. NAcc (purple), ALIC (yellow), caudate (dark blue), putamen (light blue), globus pallidus (green).

\section{Supplementary Files}

This is a list of supplementary files associated with this preprint. Click to download.

- SPIRITChecklistASDSIBprotocol.doc 